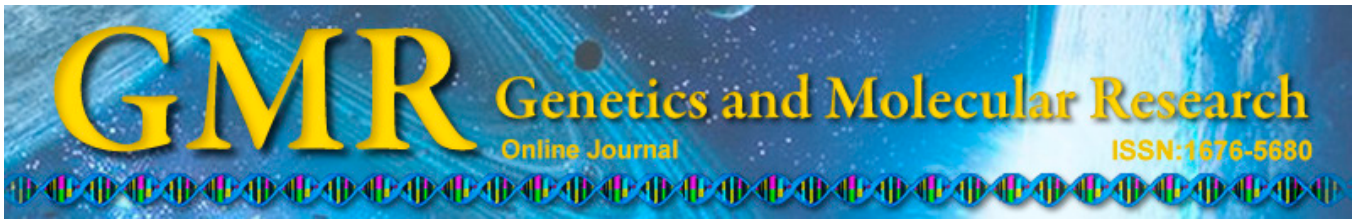

\title{
Evaluation of castor bean genotypes sown in winter and summer at a low altitude
}

\author{
G.E.M. Lopes ${ }^{1}$, H.D. Vieira ${ }^{2}$ and F.L. Partelli ${ }^{3}$ \\ ${ }^{1}$ Petrobras Biocombustível, Petrobrás, Rio de Janeiro, RJ, Brasil \\ ${ }^{2}$ Laboratório de Fitotecnia, \\ Universidade Estadual do Norte Fluminense Darcy Ribeiro, \\ Campos dos Goytacazes, Rio de Janeiro, RJ, Brasil \\ ${ }^{3}$ Departamento de Ciências Agrárias e Biológicas, \\ Centro Universitário Norte do Espírito Santo, São Mateus, \\ ES, Brasil \\ Corresponding author: H.D. Vieira \\ E-mail: henrique@uenf.br
}

Genet. Mol. Res. 13 (4): 8807-8814 (2014)

Received October 14, 2013

Accepted January 13, 2014

Published October 27, 2014

DOI http://dx.doi.org/10.4238/2014.October.27.22

\begin{abstract}
Current demands for the genetic breeding of castor bean include the adaptation of genotypes to low altitudes to expand the potential areas of cultivation. This study was conducted to evaluate the response of different genotypes of castor bean that were sown in winter and summer at a low altitude. The study was conducted in northwestern Rio de Janeiro State at an altitude of $60 \mathrm{~m}$. The treatments consisted of genotypes IAC 80, AL Guarany 2002, BRS 149 Nordestina, BRS 188 Paraguaçu, Savana, Lyra, Mirante 10, IAC 226, Cafelista, G1, V1, and T1 with spaces of 2.0 $\mathrm{m}$ between rows, $1.0 \mathrm{~m}$ between plants, and one plant per hole. The plant height, number and length of racemes, number of fruits per raceme, seed yield, and incidence of gray mold were determined. The highest yields in both seasons were obtained by the genotypes BRS 149 Nordestina, G1, BRS 188 Paraguaçu, and IAC 226. The genotypes Savannah and Lyra had the lowest yields in both cultivation seasons. The genotypes responded differently to the environmental conditions depending on the
\end{abstract}


growing season, and the spring-summer period was found to be more favorable at the low altitude of the study site.

Key words: Ricinus communis L.; Different genotypes; Planting season

\section{INTRODUCTION}

About 100,600 tons of castor oil were produced in Brazil in 2009-2010 over an area of more than 150,000 hectares, resulting in an average yield of $636 \mathrm{~kg} / \mathrm{ha}$ (CONAB, 2013). The first efforts to improve castor bean production in Brazil were carried out in the State of São Paulo in 1936 in the Campinas Agronomic Institute (Beltrão, 2004). In the 1950s, in the State of Rio de Janeiro, studies of the introduction and evaluation of castor bean varieties were conducted in Itaocara (Bayma, 1958) at the institution that is now called Pesagro-Rio.

Northwestern Rio de Janeiro is characterized by small and medium farms and a strong emphasis on family farming. The cultivation of oilseeds, including castor bean (Ricinus communis L.), stands out in the production of oils and biodiesel. Research by Petinari et al. (2012) showed that this culture can provide an operating income that exceeds US\$900 per year. Thus, soybean production gained prominence as a way to provide new alternatives for income and employment on farms in the State of Rio de Janeiro, including regions at low altitudes.

According to Beltrão (2004), the optimal conditions for the development of castor beans are found in places at altitudes between 300 and $1500 \mathrm{~m}$, an annual rainfall of at least $500 \mathrm{~mm}$, and average air temperatures between $20^{\circ}$ and $30^{\circ} \mathrm{C}$ (Amorim Neto et al., 2001). The limited elevation range that is deemed suitable for the cultivation of castor bean has excluded many municipalities. However, results obtained by various researchers (Severino et al., 2006; Diniz Neto et al., 2012) indicate that the production of castor beans at altitudes below $300 \mathrm{~m}$ and in regions with high temperatures is technically feasible.

According to Zuchi et al. (2010), the cultivars that are currently available have not been widely tested, and knowledge of their agronomic characteristics may allow the diffusion of technologies that are appropriate to each region. Therefore, the current demands for the genetic breeding of castor bean require the adaptation of genotypes to low altitudes. Thus, it is necessary to conduct research on castor bean production under these environmental conditions.

This study was conducted to evaluate the response of various genotypes of castor bean that were sown at low altitude in winter and summer.

\section{MATERIAL AND METHODS}

The experiment was conducted under field conditions at the Experimental Station of the Pesagro-Rio in the municipality of Itaocara in northwestern Rio de Janeiro State at $60 \mathrm{~m}$ of altitude. Geographically, the study area is located at $21^{\circ} 40^{\prime} 09^{\prime \prime} \mathrm{S}$ latitude and $42^{\circ} 04^{\prime} 34^{\prime \prime} \mathrm{W}$ longitude. During the assay, the weather was consistent to some extent with respect to the long-term average weather conditions. The rainfall recorded during the 2005 fall-winter season was 430 $\mathrm{mm}$, while in the 2005-2006 spring-summer season, it was $899 \mathrm{~mm}$ (Figure 1).

Various genotypes were evaluated, including IAC 80, AL Guarany 2002, BRS 149 Nordestina, BRS 188 Paraguaçu, Savana, Lyra, Mirante 10, V1, IAC 226, Cafelista, G1, and T1, and grown during the 2005 fall-winter season (sown in early March). The genotypes IAC 80, AL Guarany 2002, BRS 149 Nordestina, BRS 188 Paraguaçu, Savana, Lyra, Mirante 10, IAC 
226, Cafelista, and G1 were grown in the 2005-2006 spring-summer season (sown in October).

The soil of the study area is alluvial and clayey and the relief of the area is flat. The $0-20$-cm soil layer had a $\mathrm{pH}$ of 6.1 , an organic matter content of $1.29 \mathrm{~kg} \cdot \mathrm{dag}^{-1} \cdot \mathrm{kg}^{-1}$, and $\mathrm{P}$ (by Mehlich extractor 1) and $\mathrm{K}$ levels of 1.00 and $48 \mathrm{mg} / \mathrm{kg}$, respectively. The concentrations of $\mathrm{Ca}$, $\mathrm{Mg}, \mathrm{Al}, \mathrm{H}+\mathrm{Al}$, and total bases and the cation exchange capacity at $\mathrm{pH} 7$ were $1.8,1.0,0.0,2.1$, 3.0 , and $5.1 \mathrm{cmolc} / \mathrm{dm}^{3}$, respectively, and the base saturation was $59 \%$. The castor bean plants were fertilized according to the recommendations of Savy Filho (1997), i.e., with $300 \mathrm{~kg} / \mathrm{ha}$ of the formula 04-14-08 (NPK), in addition to topdressing with $100 \mathrm{~kg} / \mathrm{ha}$ ammonium sulfate 30 days after emergence. Weeds were controlled by manual weeding. The crop was not irrigated.

The experiment was arranged in a randomized block design with four replications. Each plot consisted of four rows that were $7 \mathrm{~m}$ long, spaced $2 \mathrm{~m}$ between rows and $1 \mathrm{~m}$ between plants, and one plant per hole, covering an area of $64 \mathrm{~m}^{2}$. The two central rows were considered useful areas, and the plants at the extremities were excluded.

In the useful area of each plot, five plants were randomly marked, and the following variables were evaluated: plant height, number of racemes per plant, length of racemes, number of fruits per raceme, and disease index for the occurrence of gray mold. The grain yield was determined at harvest for each useful plot area. The harvest was performed in stages, depending on the characteristics of each material, and drying was carried out in an open area.

Observations of the occurrence of gray mold were conducted throughout the plants' growing cycle as the racemes developed. The number of diseased racemes and the percentage of the raceme area affected were evaluated using the following rating scale: degree $0=\mathrm{a}$ healthy raceme without visible symptoms, degree $1=0-25 \%$ of the raceme is affected, degree $2=26-50 \%$ of the raceme is affected, degree $3=51-75 \%$ of the raceme is affected, and degree $4=76-100 \%$ of the raceme is affected. These grades were assigned individually for each raceme category. From the levels of disease severity, the disease index was calculated according to the methodology that was used by Lima and Soares (1990).

The data were subjected to analysis of variance, and the means were compared using the Tukey test at the $5 \%$ significance level.

\section{RESULTS AND DISCUSSION}

Analysis of variance revealed the significance $(\mathrm{P}<0.05)$ of the genetic variability among the genotypes for all traits that were evaluated in both cultivation seasons, except raceme length and number of fruits per raceme in the spring-summer (data not shown). The highest castor bean grain yield in both seasons was obtained by the genotypes BRS 149 Nordestina, G1, BRS 188 Paraguaçu, and IAC 226 (Tables 1 and 2). The genotypes Savana and Lyra had the lowest yields for the two periods of cultivation.

The highest grain yields for castor beans that were grown in the fall-winter period (Table 1) were obtained with the genotypes associated with medium to large size, especially BRS 149 Nordestina, followed by G1, V1, BRS Paraguaçu, IAC 80, and IAC 226, which had yields that were above the overall average in absolute numbers. It was also evident that in this period, the genotypes that were characterized by short stature, such as Cafelista, Lyra, and Savana, although not significantly different from the genotypes of medium to large size except BRS 149 Nordestina, had the lowest yields in absolute numbers and were below the overall average. 
Table 1. Mean plant height (H), number of racemes per plant (NR), disease index (DI), raceme length (RL), number of fruits per raceme (NF), and grain yield (GY) of genotypes of castor beans in Itaocara, RJ, in the 2005 fall-winter period.

\begin{tabular}{|c|c|c|c|c|c|c|}
\hline Genotype & $\mathrm{H}(\mathrm{cm})$ & $\mathrm{NR}(\mathrm{U})$ & DI (\%) & $\mathrm{RL}(\mathrm{cm})$ & $\mathrm{NF}(\mathrm{U})$ & GY (kg/ha) \\
\hline BRS 149 Nordestina & $284^{\mathrm{a}}$ & $7^{\mathrm{a}}$ & $42.51^{\mathrm{bc}}$ & $21^{\text {de }}$ & $32^{\mathrm{ab}}$ & $1448^{\mathrm{a}}$ \\
\hline G1 & $221^{\mathrm{ab}}$ & $4^{b}$ & $00.00^{\mathrm{c}}$ & $34^{\mathrm{ab}}$ & $39^{\mathrm{a}}$ & $1310^{\mathrm{ab}}$ \\
\hline V1 & $252^{\mathrm{a}}$ & $8^{\mathrm{a}}$ & $59.38^{\mathrm{ab}}$ & $32^{\mathrm{abc}}$ & $30^{\mathrm{ab}}$ & $1110^{\mathrm{ab}}$ \\
\hline BRS 188 Paraguaçu & $284^{\mathrm{a}}$ & $8^{\mathrm{a}}$ & $30.27^{\mathrm{bc}}$ & $17^{\mathrm{e}}$ & $19^{\mathrm{b}}$ & $1105^{\mathrm{ab}}$ \\
\hline IAC 80 & $142^{\mathrm{c}}$ & $7^{\mathrm{a}}$ & $42.31^{\mathrm{bc}}$ & $36^{\mathrm{a}}$ & $47^{\mathrm{a}}$ & $1095^{\mathrm{abc}}$ \\
\hline IAC 226 & $275^{\mathrm{a}}$ & $8^{\mathrm{a}}$ & $44.11^{\mathrm{bc}}$ & $27^{\text {bcd }}$ & $34^{\mathrm{ab}}$ & $1016^{\mathrm{abc}}$ \\
\hline AL Guarany 2002 & $165^{\mathrm{bc}}$ & $8^{\mathrm{a}}$ & $46.67^{\mathrm{bc}}$ & $35^{\mathrm{ab}}$ & $30^{\mathrm{ab}}$ & $841^{\mathrm{abc}}$ \\
\hline $\mathrm{T} 1$ & $257^{\mathrm{a}}$ & $8^{\mathrm{a}}$ & $54.43^{\mathrm{abc}}$ & $30^{\mathrm{abc}}$ & $43^{\mathrm{a}}$ & $825^{\mathrm{abc}}$ \\
\hline Cafelista & $117^{c}$ & $7^{\mathrm{a}}$ & $41.00^{\mathrm{bc}}$ & $32^{\mathrm{abc}}$ & $40^{\mathrm{a}}$ & $797^{\mathrm{abc}}$ \\
\hline Savana & $134^{\mathrm{c}}$ & $6^{\mathrm{ab}}$ & $65.68^{\mathrm{ab}}$ & $31^{\mathrm{abc}}$ & $32^{\mathrm{ab}}$ & $722^{\mathrm{bc}}$ \\
\hline Lyra & $121^{\mathrm{c}}$ & $6^{\mathrm{ab}}$ & $77.13^{\mathrm{a}}$ & $31^{\mathrm{abc}}$ & $20^{\mathrm{b}}$ & $634^{\mathrm{bc}}$ \\
\hline Mirante 10 & $257^{\mathrm{a}}$ & $7^{\mathrm{a}}$ & $51.13^{\mathrm{abc}}$ & $25^{\text {cde }}$ & $20^{\mathrm{b}}$ & $416^{\mathrm{c}}$ \\
\hline Overall average & 209 & 7 & 46.22 & 29 & 32 & 943 \\
\hline CV $(\%)$ & 14.1 & 16.4 & 23.69 & 11.8 & 22.5 & 29.1 \\
\hline
\end{tabular}

Means followed by the same letter do not differ significantly according to the Tukey test at the 5\% significance level. $\mathrm{CV}=$ coefficient of variation.

Table 2. Mean plant height (H), number of racemes per plant (NR), disease index (DI), raceme length (RL), number of fruits per raceme (NF), and grain yield (GY) of genotypes of castor beans in Itaocara, RJ, in the 2005-2006 spring-summer period.

\begin{tabular}{|c|c|c|c|c|c|c|}
\hline Genotype & $\mathrm{H}(\mathrm{cm})$ & NR (U) & DI (\%) & $\mathrm{RL}(\mathrm{cm})$ & $\mathrm{NF}(\mathrm{U})$ & $\mathrm{GY}(\mathrm{kg} / \mathrm{ha})$ \\
\hline BRS 149 Nordestina & $212^{\mathrm{ab}}$ & $7.5^{\text {bc }}$ & $4.95^{\mathrm{cd}}$ & $28^{\text {bcd }}$ & $36^{\text {bcd }}$ & $1713^{a}$ \\
\hline G1 & $231^{\mathrm{a}}$ & $3.0^{\mathrm{e}}$ & $0.00^{\mathrm{d}}$ & $36^{\mathrm{abc}}$ & $23^{\mathrm{cd}}$ & $1474^{\mathrm{a}}$ \\
\hline BRS 188 Paraguaçu & $174^{\mathrm{bc}}$ & $6.0^{\mathrm{cd}}$ & $8.47^{\text {bed }}$ & $15^{\mathrm{e}}$ & $21^{\mathrm{d}}$ & $1631^{\mathrm{a}}$ \\
\hline IAC 80 & $186^{\mathrm{bc}}$ & $4.0^{\mathrm{de}}$ & $16.04^{\mathrm{abc}}$ & $46^{\mathrm{a}}$ & $59^{\mathrm{a}}$ & $1127^{\mathrm{b}}$ \\
\hline IAC 226 & $187^{\mathrm{bc}}$ & $7.0^{c}$ & $23.21^{\mathrm{a}}$ & $38^{\mathrm{abc}}$ & $50^{\mathrm{ab}}$ & $1581^{\mathrm{a}}$ \\
\hline AL Guarany 2002 & $174^{\mathrm{ab}}$ & $4.5^{\mathrm{de}}$ & $8.68^{\mathrm{bcd}}$ & $40^{\mathrm{ab}}$ & $26^{\mathrm{cd}}$ & $1128^{\mathrm{b}}$ \\
\hline Cafelista & $113^{\mathrm{de}}$ & $3.0^{\mathrm{e}}$ & $6.87^{\mathrm{cd}}$ & $40^{\mathrm{ab}}$ & $36^{\text {bcd }}$ & $1117^{\mathrm{b}}$ \\
\hline Savana & $72.5^{\mathrm{e}}$ & $10.0^{\mathrm{ab}}$ & $25.49^{\mathrm{a}}$ & $26^{\text {cde }}$ & $27^{\mathrm{cd}}$ & $1021^{b}$ \\
\hline Lyra & $71.5^{\mathrm{e}}$ & $12.0^{\mathrm{a}}$ & $19.87^{\mathrm{ab}}$ & $21^{\mathrm{de}}$ & $37^{\mathrm{bc}}$ & $1278^{b}$ \\
\hline Mirante 10 & $184^{\mathrm{b}}$ & $10.5^{\mathrm{a}}$ & $26.07^{\mathrm{a}}$ & $21^{\text {de }}$ & $27^{\mathrm{cd}}$ & $1520^{\mathrm{a}}$ \\
\hline Overall average & 160.5 & 7.0 & 13.97 & 31 & 34 & 1359 \\
\hline CV $(\%)$ & 11.22 & 15.46 & 34.82 & 16.17 & 17.70 & 9.74 \\
\hline
\end{tabular}

Means followed by the same letter do not differ significantly according to the Tukey test at the 5\% significance level. $\mathrm{CV}=$ coefficient of variation.

The genotype Mirante 10 had the lowest yield (416 kg/ha), which is consistent with the findings of Bahia et al. (2008), who cultivated this genotype in Cruz das Almas in the State of Bahia. However, Rodrigues et al. (2010) found that Mirante 10 achieved the best results as seedlings when grown under greenhouse conditions in Lavras.

With respect to plant height, two distinct groups were observed. The tallest genotypes were BRS 188 Paraguaçu, BRS 149 Nordestina, IAC 226, Mirante 10, T1, V1, and G1, which did not differ statistically from one another, while the shortest genotypes were Savana, Lyra, Cafelista, and IAC 80, which also did not differ significantly from one another. These results are consistent with the characteristics of medium to high stature and short stature for the first and second groups, respectively. Genotype IAC 80 was an exception. It is characterized by medium stature, but it grew to only short stature during this period.

The highest grain yields for castor beans grown in the spring-summer period (Table 2) were obtained by the genotype BRS 149 Nordestina, followed by BRS 188 Paraguaçu, IAC 
226, Mirante 10, and G1 (Table 2). At this time of the year, the genotype Mirante 10 stood out as having the highest grain yield, which did not occur in the fall-winter period.

The highest yields occurred in the spring-summer period, with sowing in October, corroborating the findings of Aires et al. (2011), who investigated the sowing season of castor beans in Rio Grande do Sul. The same authors found that the greater yields were associated with higher temperatures and higher relative humidity levels.

Increased grain yield was observed for all genotypes that were evaluated in the springsummer period relative to the other growing season, mainly because of the higher temperatures and greater water availability in the spring-summer period (Figure 1A and B). During the spring-summer cultivation, $899 \mathrm{~mm}$ of rainfall were recorded, while only $430 \mathrm{~mm}$ (Figure 1B) was recorded from March to October.
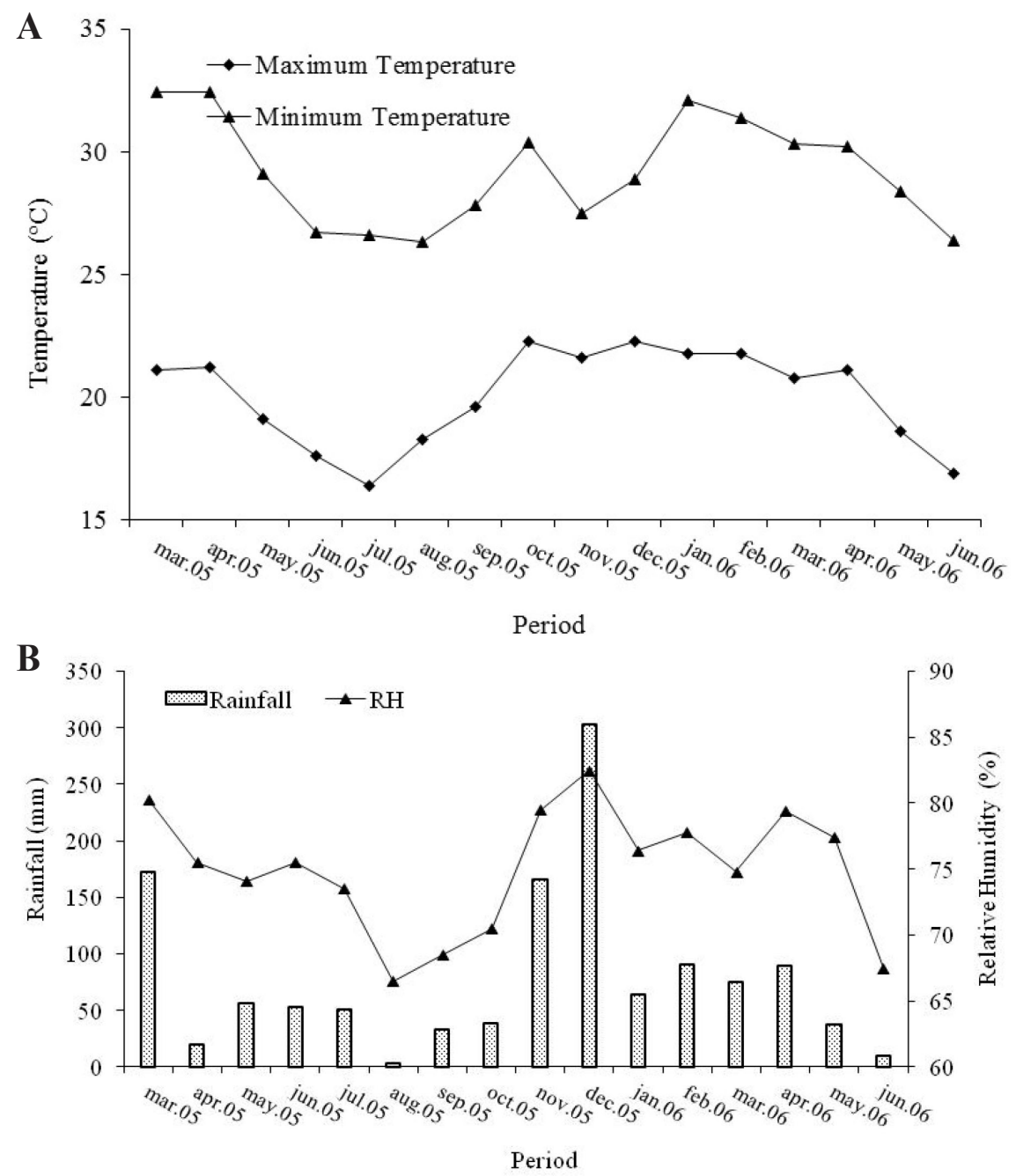

Figure 1. Average maximum and minimum air temperatures (A) and relative humidity $(\mathrm{RH})$ and total rainfall (B) recorded at the meteorological station in Itaocara, RJ, during the 2005-2006 experimental period. 
The latter amount, although small, was sufficient for the development of the culture. Another factor that may have favored the productivity of plants that were grown in the springsummer season was the lower severity of gray mold (Tables 1 and 2).

Except for genotypes G1, AL Guarany 2002, and IC 80, the genotypes exhibited a lower average plant height in the spring-summer season than in the fall-winter season. The average plant heights were reduced by the following percentages: Savana (46\%), Lyra (41\%), BRS 189 Paraguaçu (38\%), IAC 226 (32\%), Mirante 10 (28\%), BRS 149 Nordestina (25\%), and Cafelista (3.4\%). The reduced plant height may possibly have been due to the physical attributes of the soil where the experiment was conducted, which is an alluvial soil that is subject to drainage problems in the rainy season and received an excess of water in November and December 2005. This may have affected the vegetative growth of some genotypes that are less tolerant to poor drainage conditions, as noted by Beltrão et al. (2003), who observed that excess water reduced the height of the castor bean plant BRS 188 Paraguaçu compared to water deficiency stress.

The G1 genotype showed no visible symptoms of disease under field conditions, with a disease index of zero for both growing seasons, and it may become a source of resistance to gray mold. However, further research is necessary. Rêgo Filho et al. (2007) reported that the genotype G1 stood out for the low incidence of gray mold that it exhibited during the fallwinter season at low altitude in Campos dos Goytacazes in Rio de Janeiro State. According to Milani et al. (2005), gray mold is considered to be the most important disease affecting castor bean plants in many regions of Brazil. Therefore, the use of cultivars that are resistant to this disease is an effective and desirable management practice. However, cultivars with high levels of resistance to this disease are still under development in Brazil.

A higher incidence of gray mold was observed during the fall-winter season than in the other period under study as indicated by the disease index values (Tables 1 and 2). The climate of northwestern Rio de Janeiro State is characterized by a high relative humidity and mild temperatures during the fall-winter season (Figure 1A and B), which may explain the high incidence of gray mold that was possibly due to the reduced average temperature associated with the high relative humidity during this period.

Recent study that was carried out by Aires et al. (2011) and Sussel et al. (2011) confirmed that higher rates of rainfall, artificial wetness, clouds, and high relative humidity provide more favorable conditions for disease development. Rêgo Filho et al. (2007) evaluated the development of gray mold in castor bean genotypes during the fall-winter season in Campos, RJ, and noted that disease incidence increased progressively during the season as temperatures decreased and that the peak incidence of the disease occurred in July.

During the spring-summer season, temperatures remained high in the region (Figure 1A), possibly contributing to the reduced development of gray mold. Despite the high relative humidity, symptoms of gray mold were first observed in April, when temperatures began to fall (Figure 1A).

The genotypes that were associated with small size were more severely affected by gray mold, possibly due to their more compact plant architecture, which is a trait of these genotypes that favors higher moisture retention and progression of the disease. This may be the main cause of the low yields of these genotypes during the fall-winter period. According to Milani et al. (2005), more open plants are less affected by disease than compact plants and plants whose racemes are above the leaves because compact plants and plants with inflores- 
cence surrounded by leaves form a microclimate that is conducive to fungal growth.

In general, the genotypes associated with medium to large size had the highest grain yields, which were above the overall average in absolute numbers. These were mainly BRS 149 Nordestina, BRS 189 Paraguaçu, IAC 226, Mirante 10, and G1. Exceptions were observed for the genotypes AL Guarany 2002 and IAC 80, which had yields that were below the overall average, most likely due to the low number of racemes emitted by the plants in the spring-summer period.

The short-sized genotypes Lyra, Savana, and Cafelista had yields below the average, in absolute numbers, possibly because the spacing between them was the same as that of the genotypes of medium to large size, which may have prevented the expression of its productive potential. This effect was also observed and reported by Severino et al. (2006). Thus, further studies are needed to evaluate genotypes that are associated with short stature in different population arrangements to obtain more conclusive data.

The cultivation of castor beans is considered to be economically unviable in environments at altitudes below $300 \mathrm{~m}$ because of the high temperatures that are typical of these regions, which intensifies respiratory metabolism and leads to higher consumption of photosynthesized reserves. However, in the two growing seasons that were evaluated in this study, the yields of even the lower yielding genotypes (except Mirante 10 during the fall-winter season) were well above the national average of $601.5 \mathrm{~kg} / \mathrm{ha}$ for the historical series from 1976-77 to 2009-10 (CONAB, 2013), which suggests the feasibility of castor bean cultivation in regions that are close to sea level.

The adverse effects of high temperatures on the net rate of photosynthesis of different castor bean genotypes were significant only when they were associated with high vapor pressure deficits (Kumar and Vanaja, 2004). Thus, in regions of low altitude with good soil water availability and high relative air humidity, the negative effects of high temperatures on castor bean yield can possibly be mitigated, as indicated by the results of this study.

The results of this study are also consistent with those that were obtained by Severino et al. (2006), who demonstrated the technical feasibility of the cultivation of castor beans at altitudes below $300 \mathrm{~m}$ in regions with high temperatures. Severino et al. (2006) evaluated 10 genotypes of castor bean in three different places in the semi-arid region of northeast Brazil at altitudes below $300 \mathrm{~m}$ and reported an average yield of $1402.5 \mathrm{~kg} / \mathrm{ha}$ for the three sites and variations from 621.1 to $1825.1 \mathrm{~kg} / \mathrm{ha}$ among the genotypes.

The results of this study, together with other results reported in the literature, suggest that the cultivation of castor beans at altitudes below $300 \mathrm{~m}$ is viable and can achieve yields well above the historical Brazilian average provided that suitable genetic materials and appropriate management techniques are used.

\section{CONCLUSIONS}

Castor bean yields that are well above the national average can be achieved in areas of low altitude. In this study, the highest castor bean grain yields were obtained with the genotypes BRS 149 Nordestina, G1, BRS 188 Paraguaçu, and IAC 226 in both cultivation seasons. The genotypes Savana and Lyra had the lowest yields in both seasons. The different genotypes that were studied responded differently to the environmental conditions of the growing seasons, with the spring-summer period being the more favorable. 


\section{REFERENCES}

Aires RF, Silva SDA and Eicholz ED (2011). Análise de crescimento de mamona semeada em diferentes épocas. Cienc. Rural 41: 1347-1353.

Amorim Neto MS, Araújo AE and Beltrão NEM (2001). Zoneamento agroecológico e época de semeadura para a mamoneira na Região Nordeste do Brasil. Rev. Bras. Agrometeorol. 9: 551-556.

Bahia HF, Silva SA, Fernandez LG and Ledo CAS (2008). Divergência genética entre cinco cultivares de mamoneira. Pesq. Agropec. Bras. 43: 357-362.

Bayma C (1958). Mamona. Ministério da Agricultura, Serviço de Informação Agrícola, Rio de Janeiro.

Beltrão NEM (2004). A Cadeia da Mamona no Brasil, com Ênfase Para o Segmento P\&D: Estado de Arte, Demandas de Pesquisa e Ações Necessárias Para o Desenvolvimento. Empresa Brasileira de Pesquisa Agropecuária, Brasília.

Beltrão NEM, Souza JG and Santos JW (2003). Estresse hídrico (deficiência e excesso) e seus efeitos no crescimento inicial da mamoneira, cultivar BRS 188 Paraguaçu. Rev. Bras. Oleaginosas Fibrosas 7: 735-741.

CONAB (Companhia Nacional de Abastecimento) (2013). Série Histórica: Mamona. Available at [http://www.conab.gov. br/conteudos.php?a=1252\&t=2\&Pagina_objcmsconteudos=2\#A_objcmsconteudos]. Accessed September 11, 2013.

Diniz Neto MA, Silva IF, Diniz BLMT and Pereira AA (2012). Componentes de produção de mamona em função de níveis de adubação nitrogenada e desfolha. Rev. Cienc. Agron. 43: 546-553.

Kumar VP and Vanaja M (2004). Effect of weather parameters on photosynthesis in four castor bean genotypes. Indian J. Plant Physiol. 9: 442-446.

Lima EF and Soares JJ (1990). Resistência de cultivares de mamoneira ao mofo cinzento causado por Brotrytis ricini. Fitopatol. Bras. 15: 96-97.

Milani M, Nóbrega MBM, Suassuna ND and Coutinho WM (2005). Resistência da mamoneira (Ricinus communis L.) ao mofo cinzento causado por Amphobotrys ricini. Empresa Brasileira de Pesquisa, Brasília.

Petinari RA, Soratto RP, Souza-Schlick GD and Zanotto MD (2012). Custos de produção e lucratividade de cultivares de mamona em diferentes arranjos de plantas. Pesq. Agropec. Trop. 42: 143-149.

Rêgo Filho LM, Bezerra Neto FV and Santos ZM (2007). Avaliação da Incidência de Mofo Cinzento em Genótipos de Mamoneira no Período de Outono-Inverno em Campos dos Goytacazes-RJ. Anais do $2^{\circ}$ Congresso da Rede Brasileira de Tecnologia de Biodiesel, Brasília.

Rodrigues HCA, Carvalho SP, Souza HA and Carvalho AA (2010). Cultivares de mamoneira e adubação nitrogenada na formação de mudas. Acta Sci. Agron. 32: 471-476.

Savy Filho A (1997). Mamona. In: Recomendações de Adubação e Calagem Para o Estado de São Paulo. 2nd edn. (Raij B, Cantarella H, Quaggio JA and Furlani AMC, eds.). Instituto Agronômico, Campinas.

Severino LS, Milani M, Moraes CRA and Gondim TMS (2006). Avaliação da produtividade e teor de óleo de dez genótipos de mamoneira cultivados em altitude inferior a 300 metros. Rev. Cienc. Agron. 37: 188-194.

Sussel AAB, Pozza EA, Castro HA and Lasmar EBC (2011). Incidência e severidade do mofo-cinzento-da-mamoneira sob diferentes temperaturas, períodos de molhamento e concentração de conídios. Summa Phytopathol. 37: 30-34.

Zuchi JC, Bevilaqua GAP, Zanuncio JC and Peske ST (2010). Características agronômicas de cultivares de mamona em função do local de cultivo e da época de semeadura no Rio Grande do Sul. Cienc. Rural 40: 501-506. 